\title{
POTENTIAL IMPACTS OF THE EU CIRCULAR ECONOMY PACKAGE ON THE UTILIZATION OF SECONDARY RESOURCES
}

\author{
Johann Fellner *, David Laner, Rainer Warrings, Kerstin Schustereder and Jakob Lederer
}

Christian Doppler Laboratory for Anthropogenic Resources, Institute for Water Quality, Resource and Waste Management, TU Wien, Karlsplatz 13/226, 1040 Vienna, Austria

Article Info:

Received:

25 January 2018

Revised:

4 April 2018

Accepted:

20 June 2018

Available online:

30 June 2018

Keywords:

Circular Economy

Recycling

Packaging Waste

Secondary Raw Materials

Material Flow Analysis

\begin{abstract}
The dependency of the European Union on the imports of primary raw materials was one of the major drivers for the release of the circular economy strategy, in which resource input and waste, emission, and energy leakage are minimised by closing material loops. As part of the shift towards a circular economy, proposals introducing new waste-management targets regarding reuse, recycling and landfilling have been made. In this study the potential impact of these new targets for packaging waste (PW) and Municipal Solid Waste (MSW) on the EU's supply of four raw materials, namely Iron \& Steel, Aluminium, Plastics and Paper \& Board, has been assessed. Thereto the method of material flow analysis has been applied in order to evaluate current and potential future flows of secondary raw material. The results of the investigations indicate that for Iron \& Steel and Paper \& Board already today about $50 \%$ of the EU's production is made out of secondary raw materials. For Aluminium (36\%) and Plastics (10\%) this share however is significantly lower. Implementing higher recycling targets according to circular economy package would increase the domestic supply of secondary materials between $0.6 \%$ (Iron \& Steel) and $70 \%$ (Plastics). Since today significant amounts of recyclables (equivalent to more than $10 \%$ of the total domestic raw material consumption) are already not utilized by the European industry but exported, it is highly questionable whether these additional quantities of recyclables derived from post-consumer waste will substitute primary raw materials in the EU. Quality constraints of the industry as well as production capacities for secondary raw materials in place might limit the domestic utilization of recyclables liberated by the circular economy. Hence, additional policy measures (e.g. targets for secondary production) seem to be necessary to enhance the rate of secondary production within the European Union.
\end{abstract}

\section{INTRODUCTION}

In December 2015 the European Commission has released an action plan for a circular economy (COM / 2015 / 0614 Circular Economy Package CEP). This action plans demands a "transition to a more circular economy, where the value of products, materials and resources is maintained in the economy for as long as possible, and the generation of waste is minimized, which is seen as an essential contribution to the EU's efforts to develop a sustainable, low carbon, resource efficient and competitive economy." Within this action plan for a circular economy waste management plays a central role. The released proposal contains quantitative targets for the reduction and recycling of wastes. By the year 2030, for instance, $65 \%$ of the municipal waste and moreover $75 \%$ of packaging waste generated have to be recycled or prepared for reuse, while landfilling of all wastes should be reduced to $10 \%$ in each member state. Moreover separately collected wastes are completely banned from landfilling. All these measures are believed to contribute to the development of a sustainable and resource-efficient economy in Europe. This requires that the additionally generated secondary resources are utilized by European industries to a greater extent. At present large quantities of waste derived raw materials (including waste paper, scarp metals, or waste Plastics) are exported out of the European Union, suggesting an existing surplus of secondary resources.

Hence, the aim of the present paper is to analyze the current flows of secondary resources for selected commodities in the EU and to predict their future quantities in case that the Circular Economy Package, and in particular its recycling targets for packaging waste and MSW are fully implemented.

Besides a quantitative analysis, also qualitative aspects 
of secondary resources and their impacts on the recovery/ export will be discussed. The investigations focus on the following commodities: Iron \& Steel, aluminum, Plastics, and Paper \& Board.

\section{MATERIALS AND METHODS}

\subsection{Material Flow Analysis of Status quo}

In a first step, a material flow analysis MFA (Brunner and Rechberger, 2004) for each commodity has been conducted. Thereby a systematic assessment of all materials flows in the European Union has been accomplished. In particular, the following data have been collected for Paper \& Board, Plastics, Iron \& Steel, and aluminum for the EU-28:

- Domestic production and consumption of raw materials (indicated as raw material and finished goods in Figure 1);

- Net imports or exports of commodities via semis, finished products, End of Life products (mostly vehicles) and wastes (indicated as net exports of semis and finished goods, net export of recyclables and export of EoL products in Figure 1);

- Waste production divided into MSW, other wastes, production waste and processing or internal waste (indicated as internal scrap, production waste/new scrap, MSW and other wastes in Figure 1);

- Material losses during production (indicated as material losses in Figure 1);

- Net stock increase within the EU (indicated as stock increase of the consumption process in Figure 1)

- Final disposal paths or recycling of waste (indicated as waste to incineration, waste to landfill and recyclables/ scarp in Figure 1).

In general, the MFA was conducted at a rather superficial (highly aggregated) level, meaning a low level of detail. The MFA model used for the analysis of the commodity flows is present in Figure 1. It basically consists of four processes, namely Raw Material Production, Manufacturing \&
Trade, Consumption, and Waste Management. The spatial system boundary is the European Union (EU-28), whereby primary raw materials (nonetheless whether they are extracted within or outside the EU) are considered as imports into the system. On the other hand waste (e.g. waste Plastics, waste Paper \& Board) thermally utilized or landfilled are accounted for as exports, although the respective processes (e.g. waste-to-energy plants, landfills) are located within the European Union. For the temporal system boundary one "average" year representative for the period 2014 to 2016 was chosen. This was mainly necessary due to the fact that not all data were available for same year.

The "commodities flows" considered include primary raw materials demanded, raw material produced, material losses during raw material production, the net import of semis and finished products, finished good, production or manufacturing waste, Municipal Solid Waste (MSW), all other wastes, net exports of recyclables and end of life products (vehicles and electronic waste), as well as wastes landfilled or incinerated.

\subsection{Assessment of future material flows}

In a second step the management of MSW and packaging waste with respect to the four commodities has been investigated in detail. This was done in order to evaluate the status quo and to assess the potential impact of the Circular Economy Package (namely increased recycling targets for packaging waste and MSW) on the overall domestic supply with secondary resources. For simplicity reasons it was assumed that recycling targets for packaging wastes are also applicable to the alike materials present in MSW.

For the additionally provided secondary resources two "extreme" scenarios are basically possible: On one hand, all additional quantities of recyclables and scrap might be utilized within the European Union. On the other hand the amount of recyclables/scrap liberated by the implementation of a circular economy is exported and thus not utilized by European industry. Based on historical data about supply, utilization and export of recyclables it has been dis-

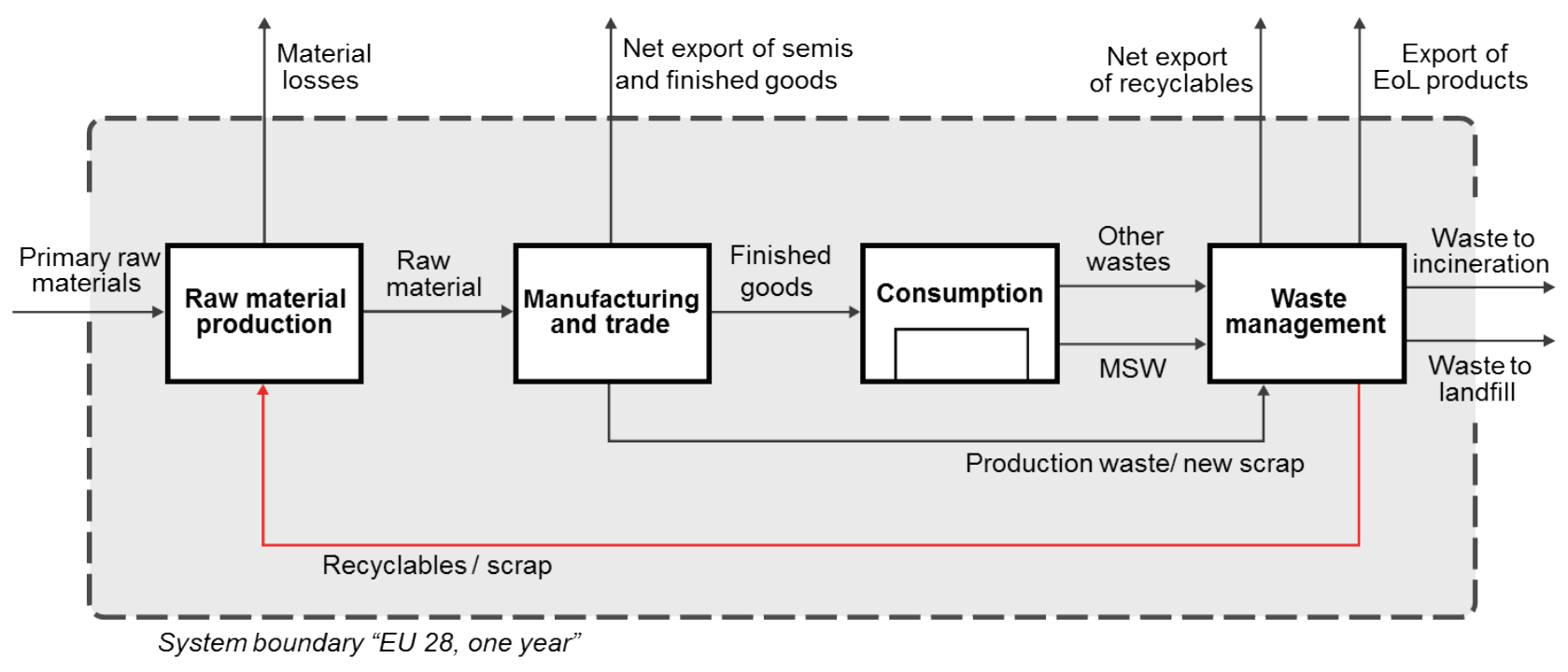

FIGURE 1: Model used to analyse the material flows of Iron \& Steel, Aluminium, Plastics and Paper \& Board within the EU-28. 
cussed which of the two options (domestic utilization or export of recyclables) is likely to prevail.

\subsection{Evaluation of Circularity}

Based on the results of the MFA it is possible to assess the current and potential future share of primary and secondary production for the different commodities. In order to quantify these shares the following indicators are calculated:

\section{- Share of secondary production (SSP)}

SSP $=\frac{\text { purchased scrap (recyables) utilized }}{\text { amount of sellable commodity produced }}$

- Share of secondary "resource losses" due export of waste and end of life products (SSL)

$S S L=\frac{\text { net export of scrap (recyables) }+ \text { export of end of life products }}{\text { amount of sellable commodity produced }}$

- Share of secondary production for the final domestic consumption (SSC)

$S S C=\frac{\operatorname{scrap}(\text { recyables }) \text { utilized }}{\text { amount of commodity domestically consumed }}$

In addition current and potential future reductions of greenhouse gas emissions due to the utilization of secondary raw materials are calculated. Thereto Life Cycle Assessment LCA data (after Ecoinvent \& Turner et al., 2015) are used. In practice, the following specific greenhouse gas emission factors (expressed in $\mathrm{kg} \mathrm{CO}$, equivalents per $\mathrm{kg}$ of commodity related to the primary and secondary production of the four commodities are applied (see Table 1).

\subsection{Data collection}

A wide range of different data sources was needed to establish the material budgets for Iron \& Steel, aluminum, Plastics and Paper \& Board of the EU-28.

For the Paper \& Board, data were mainly derived from the Confederation of European Paper Industry, which publishes annual statistics about production of pulp and paper and therefore utilized raw materials (CEPI, 2016). In addition, the data of the CEWPI statistics have been complemented and crosschecked with MFA figures recently published on paper recycling in the EU (Pivnenko et al., 2016).

For Plastics most data used for the budget (e.g. production, consumption, recycling, waste to landfill, waste to incineration) have been obtained from Plastics Europe (Plastics Europe, 2016). Information about the export of recyclable Plastics was retrieved from a study recently conducted by Verlis (2014). Furthermore, Plastics exported via end of life products was assessed using data about the composition (Plastics content) of vehicles and estimates about the (official and unofficial) exports of end of life vehicles. For the latter a total number of approximately 5 million passenger cars was assumed according to Oe-
ko-Institut e.V. (2016). The assignment of waste Plastics to MSW and other wastes was accomplished in accordance to information provided by Van Eygen et al. (2017).

For European flows of aluminum (including data about production, consumption, scrap generation), comprehensive data sets for the last years were provided by the European Aluminium Association (2016). Exports of Al scrap was obtained from the UN Comtrade database and exports via end of life products were estimated in analogy to plastic flows. Al flows through MSW were assessed using data about production statistics (Al used in packaging) and information provided by Buchner et al. (2015) and Warrings and Fellner (2017).

Information about Iron \& Steel production and consumption as well as data about scrap generation were obtained from the European Steel Association Eurofer (Eurofer, 2017). In addition the generation of internal (home) and production scrap was estimated using data (ratio between steel production and scrap generation) provided by Ghenda and Lüngen (2013) and Wang et al. (2007). Iron \& Steel exported via end of life products (mainly due to end of life vehicles) were estimated in analogy to alike exports of Plastics or aluminum. For the estimation of Iron \& Steel present in MSW, data of waste sorting analyses from different countries (Germany, Denmark, Austria, Croatia and Sweden) were used.

\section{RESULTS AND DISCUSSIONS}

\subsection{Present Recycling Rates for Iron \& Steel, Alu- minium, Plastics and Paper \& Board}

The results of the material flow analyses reveal that for Iron \& Steel (SSP $=46.4 \%)$ and Paper \& Board (SSP=52.4\%) secondary production is equally important as primary production. For aluminum, almost $37 \%$ of the sellable production originates from scrap. In contrast, only about $10 \%$ of the Plastics produced in the EU are made out of secondary raw materials. In addition, it can be assumed that these secondary Plastics only partly substitute primary Plastics. This assumption is based on the fact that secondary Plastics produced in the EU contain to a large extent mixed-polymer re-granulates, which are used for garden benches, roof tiles or other products, which would usually not be made out of Plastics.

A significant share (between 42 and 47\%) of the final consumption of commodities (except for Paper \& Board) contributes to an increase of anthropogenic material stocks in the EU. The annual stock growth amounts in absolute figures to $55,000 \mathrm{kt}$ for Iron \& Steel, to $4,700 \mathrm{kt}$ for aluminum and 22,000 kt for Plastics (equal to $110 \mathrm{~kg}$ / cap/y for Iron \& Steel, $9.4 \mathrm{~kg} \mathrm{~kg} / \mathrm{cap} / \mathrm{y}$ for Aluminium and $44 \mathrm{~kg} / \mathrm{cap} / \mathrm{y}$ for Plastics - see Figure 2 to 5). This observation demonstrates that even in a highly developed econo-

TABLE 1: Greenhouse gas emissions factors used for the four commodities (based on Turner et al., 2015).

\begin{tabular}{|c|c|c|c|c|}
\hline $\begin{array}{c}\text { Greenhouse gas emissions } \\
{[\mathrm{kg} \mathrm{CO}, \mathrm{eq} / \mathrm{kg}]}\end{array}$ & Iron \& Steel & Aluminum & $\begin{array}{c}\text { Plastics } \\
\text { (mixture of PE, PP \& PET) }\end{array}$ & Paper\& board \\
\hline Primary production & 2.3 & 9.2 & 1.8 & 0.68 \\
\hline Secondary production & 0.7 & 1.1 & 0.3 & 0.56 \\
\hline
\end{tabular}




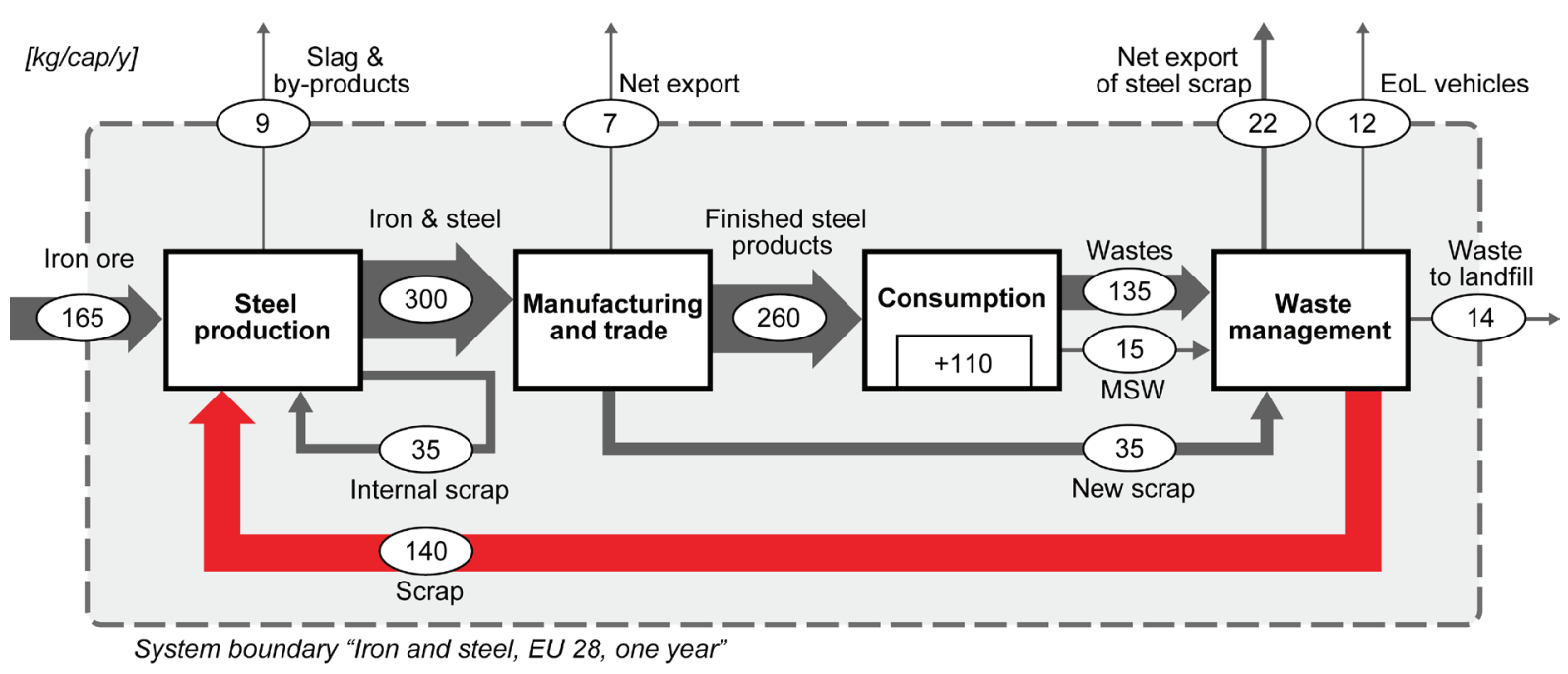

FIGURE 2: Annual Iron \& Steel flows in the EU-28 including the stock increase in the consumption process (data given in $\mathrm{kg} / \mathrm{cap} / \mathrm{y}$ ), since the data of the different sources have not been reconciled, the flows of some processes are slightly unbalanced.

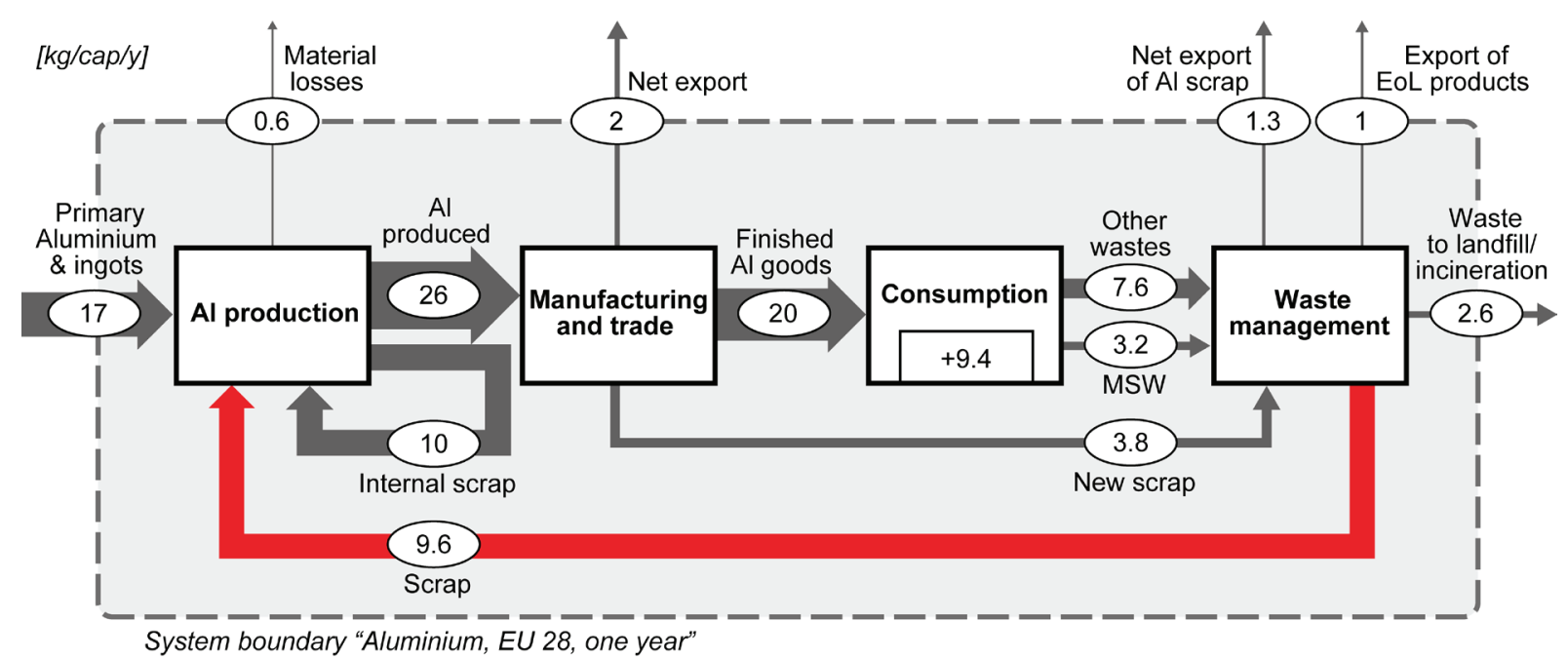

FIGURE 3: Annual Aluminium flows in the EU-28 including the stock increase in the consumption process (data given in $\mathrm{kg} / \mathrm{cap} / \mathrm{y}$ ); since the data of the different sources have not been reconciled, the flows of some processes are slightly unbalanced.

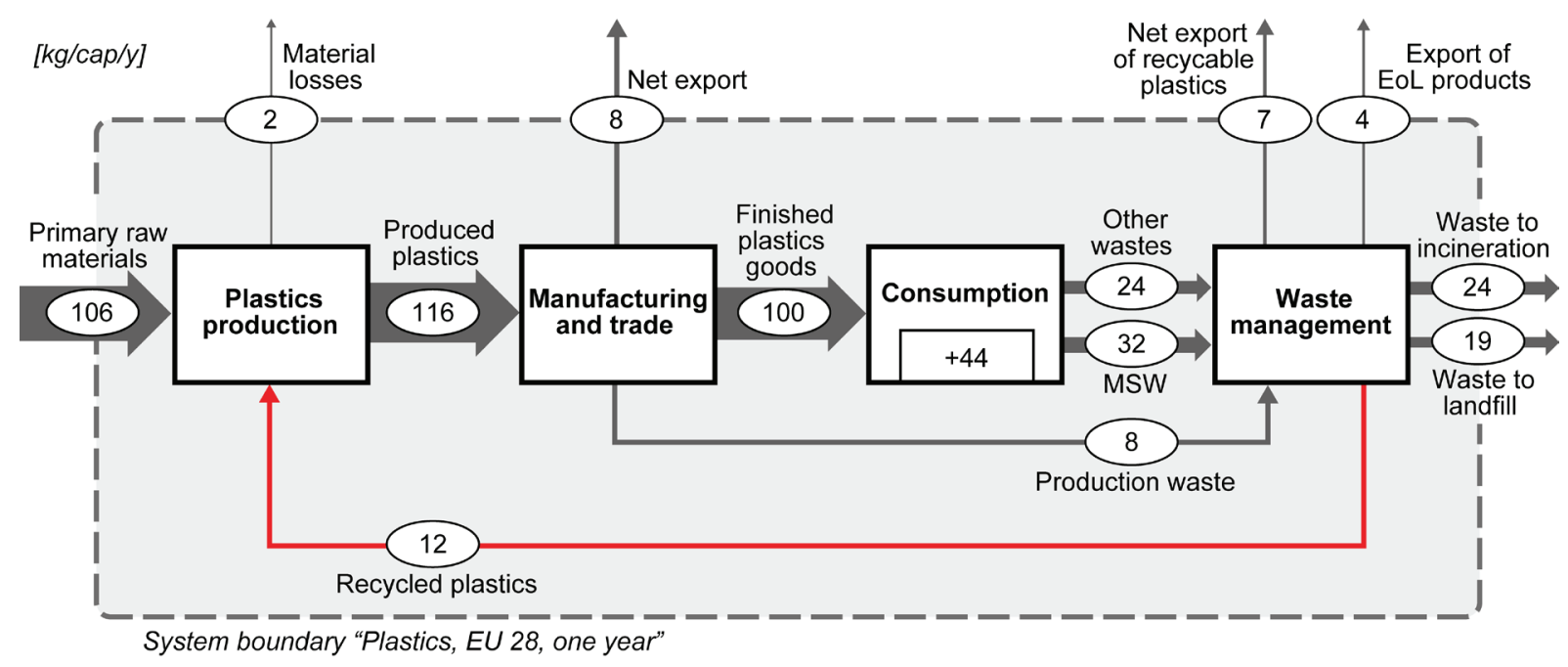

FIGURE 4: Annual plastic flows in the EU-28 including the stock increase in the consumption process (data given in $\mathrm{kg} / \mathrm{cap} / \mathrm{y}$ ); since the data of the different sources have not been reconciled, the flows of some processes are slightly unbalanced. 


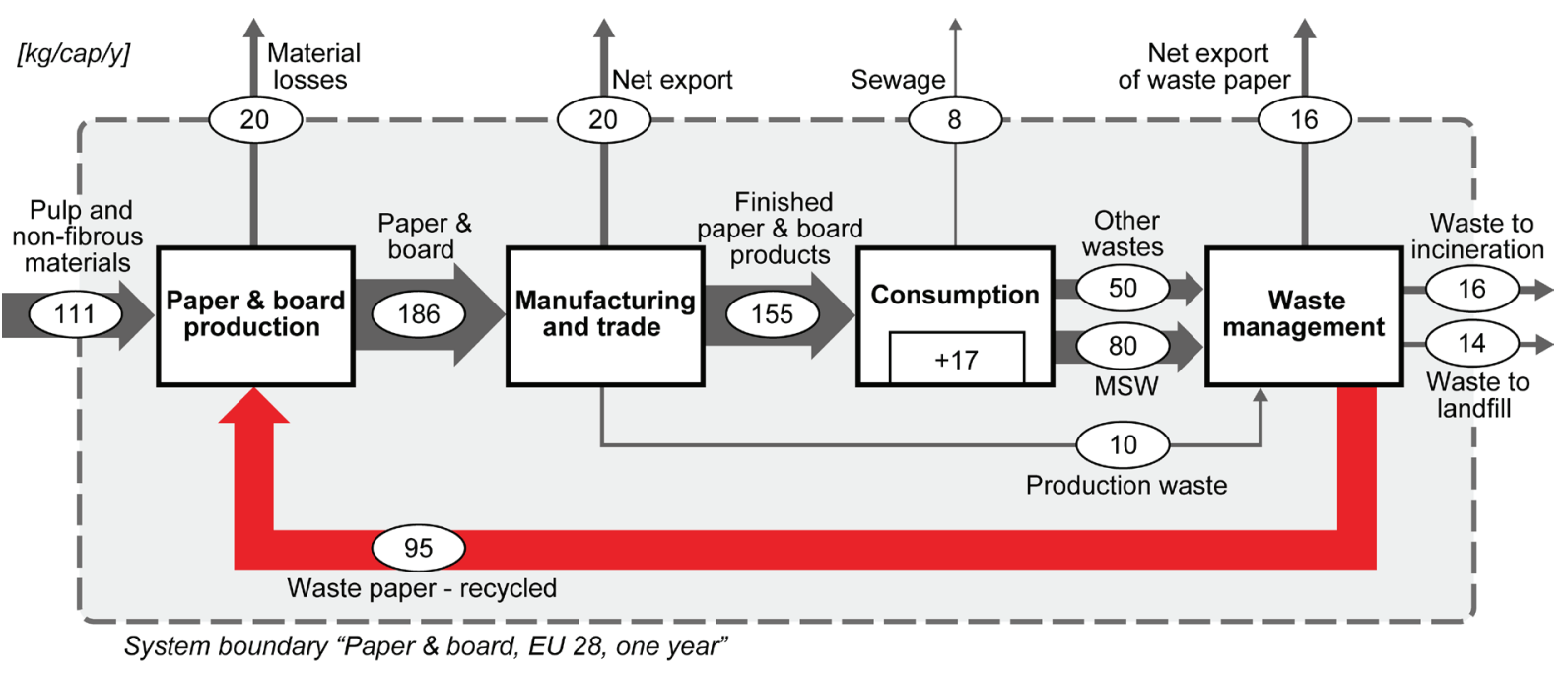

FIGURE 5: Annual Paper \& Board flows in the EU-28; including the stock increase in the consumption process (data given in $\mathrm{kg} / \mathrm{cap} / \mathrm{y}$ ); since the data of the different sources have not been reconciled, the flows of some processes are slightly unbalanced.

my like the European Union societies' material flows are far from being balanced (input > output of materials), thereby limiting the overall potential of a circular economy to substitute primary resources.

Furthermore, for all four commodities a significant export of recyclables/scrap is observable. In case that besides the exports of recyclables also "hidden" material exports via end of life products are accounted for, the total "resource" losses (SSL) for the European industry amounts to approximately $10 \%$ for all four commodities. This implies that terminating exports of recyclables/scrap and end of life products could potentially increase the share of secondary production SSP in the EU by almost 10\% (absolute). This is based on "highly questionable" assumptions, such as that there are no quality constraints for recycling and production facilities and capacities in place could handle this increased quantity of recyclables and scrap, respectively.

Referred to the final domestic consumption of the four commodities, the current share of supply via secondary resources SSC amounts to $54 \%$ for Iron \& Steel, $48 \%$ for aluminum, $12 \%$ for Plastics and $61 \%$ for Paper \& Board.
With respect to greenhouse gas emissions the current substitution rate of primary resources by utilizing waste derived materials results in total savings of $165 \mathrm{Mt} / \mathrm{a}(330 \mathrm{~kg} /$ cap/y), which represents about 3.7\% of EU's current greenhouse gas emissions.

\subsection{Potential Impact of the Circular Economy Pack- age (for MSW \& packaging waste) on the Recycling Rates of Iron \& Steel, Aluminium, Plastics and Paper \& Board}

Based on the current "commodity flows", the potential impact of implementing the circular economy package for MSW and packaging waste was assessed. Thereto it was assumed that the recycling targets proposed are met and the thereby additionally recovered recyclables / scrap (in comparison to the status quo) are fed into the European recycling market.

In Table 2 the current management of packaging waste and MSW with respect to the four commodities is summarized. It is obvious that for Iron \& Steel and as well as for Paper \& Board current recycling rates are already close to target values proposed by the Circular Economy Package

TABLE 2: Quantities of recyclables derived from packaging waste and MSW (current status versus fulfilment of the Circular Economy targets for packaging waste and MSW ${ }^{1}$ ).

\begin{tabular}{|c|c|c|c|c|c|}
\hline & Unit & Iron \& Steel & Aluminum & Plastics & Paper \& Board \\
\hline $\begin{array}{l}\text { Total packaging waste \& non packaging } \\
\text { present in MSW }\end{array}$ & [kg/cap/y] & 15 & 3.2 & 44 & 125 \\
\hline $\begin{array}{l}\text { Current recycling rates (packaging \& non } \\
\text { packaging) }{ }^{2}\end{array}$ & [\%] & $77.5 \%$ & $47 \%$ & $23 \%$ & $83 \%$ \\
\hline $\begin{array}{l}\text { Current quantities of recyclables derived } \\
\text { from packaging waste and MSW }\end{array}$ & {$[\mathrm{kg} / \mathrm{cap} / \mathrm{y}]$} & 12 & 1,5 & 11 & 104 \\
\hline $\begin{array}{l}\text { Recycling targets (according to the } \\
\text { Circular Economy Package CEP) }{ }^{3}\end{array}$ & [\%] & $85 \%$ & $85 \%$ & $55 \%$ & $85 \%$ \\
\hline $\begin{array}{l}\text { Additional quantities of recyclables } \\
\text { (implementation of CEP) }\end{array}$ & [kg/cap/y] & 1.1 & 1.2 & 13 & 2.5 \\
\hline
\end{tabular}

${ }^{1}$ For simplicity reasons it was assumed that recycling targets for packaging wastes are also applicable to the alike materials present in MSW.

${ }^{2}$ Based on EUROSTAT data about recycling rates for packaging waste by material and considering recycling rates for non-packaging material present in MSW. ${ }^{3}$ Until 2030. 
(85\%), whereas for Aluminium (47\%-85\%) and Plastics (30\%-55\%) substantial improvements would be necessary to the met the targets. It needs to be noted that for simplicity reasons it was assumed that recycling targets proposed for packaging waste are likewise applied for non-packaging materials present in MSW.

Based on the necessary improvements (increase) of recycling rates and the quantities of materials present in packaging waste and MSW, the impact of the proposed circular economy in terms of additional quantities of recyclables / metal scrap as well as potential savings of greenhouse gas emissions were calculated.

\subsubsection{Iron \& Steel}

For Iron \& Steel the achievement of a recycling target of $85 \%$ would imply an additional amount of $1.1 \mathrm{~kg}$ of scrap per capita and year (or $550 \mathrm{kt} / \mathrm{a}$ for the EU-28). This represent about $0.6 \%$ of EU's total ferrous metal scrap generation. If the total amount of additional scrap would be utilized by the European steel industry (no export of this additional scrap), the share of secondary production (SSP) would marginally increase by $0.36 \%$ to $47 \%$. In case that also home scarp is considered, the share of secondary production for Iron \& Steel would reach almost 55\% (see Figure 6) In terms of greenhouse gas emissions this increased scrap supply / utilization would results in reductions of less than $2 \mathrm{~kg} \mathrm{CO}$,eq/cap/y, neglecting the efforts for the collection / separation and sorting of the scrap.

\subsubsection{Aluminum}

For Aluminium an achievement of the proposed recycling target of $85 \%$ would translate in an additional scrap quantity of $1.2 \mathrm{~kg} / \mathrm{cap} / \mathrm{y}$ (or in total $600 \mathrm{kt} / \mathrm{a}$ ). This would increase the current quantities of Al scrap available $(9.6 \mathrm{~kg} /$ cap/y) by $11 \%$. In case that all the additional quantities are utilized by European Al smelters, the share of secondary production (SSP) would theoretically increase by almost $5 \%$ to $41.5 \%$. In terms of greenhouse gas emissions this would be associated with reductions of about $10 \mathrm{CO}_{2}, \mathrm{eq} /$ cap/y. However, it is highly questionable whether such raise in Al scrap supply could be absorbed by the European manufactures. It is more likely that these quantities are at least to some extent exported for recycling, as it was observable for iron scrap (see Figure 6). There higher shares of scrap in relation to the production volume, expressed as potential share of secondary production (light blue bars in Figure 6), did not translate into higher secondary production (dark blue bars in Figure 6). The "additional" quantities of scrap were not utilized by the European steel makers and hence exported.

\subsubsection{Plastics}

For Plastics alike to Aluminium current recycling rates (23\%) would almost need to double to reach the target value of $55 \%$ proposed by the circular economy package. Such an increase would generate an additional quantity of recyclable Plastics of almost $13 \mathrm{~kg} / \mathrm{cap} / \mathrm{y}(6,500 \mathrm{kt} / \mathrm{a})$. In comparison to the status quo ( $19 \mathrm{~kg} / \mathrm{cap} / \mathrm{y})$, this would rise the recyclable quantities by more than $65 \%$. Considering that already today a significant share of Plastics is exported for recycling $(7 \mathrm{~kg} / \mathrm{cap} / \mathrm{y})$, it might be questioned if huge amounts of additional quantities of recyclables will be utilized within the European Union. In general, higher collection and sorting rates will most likely lower the quality of the recyclable Plastics obtained, which further challenges the production of high quality re-granulates able to substitute primary polymers. It is more likely that the collected materials are down-cycling (e.g. mixed polymer re-granu-

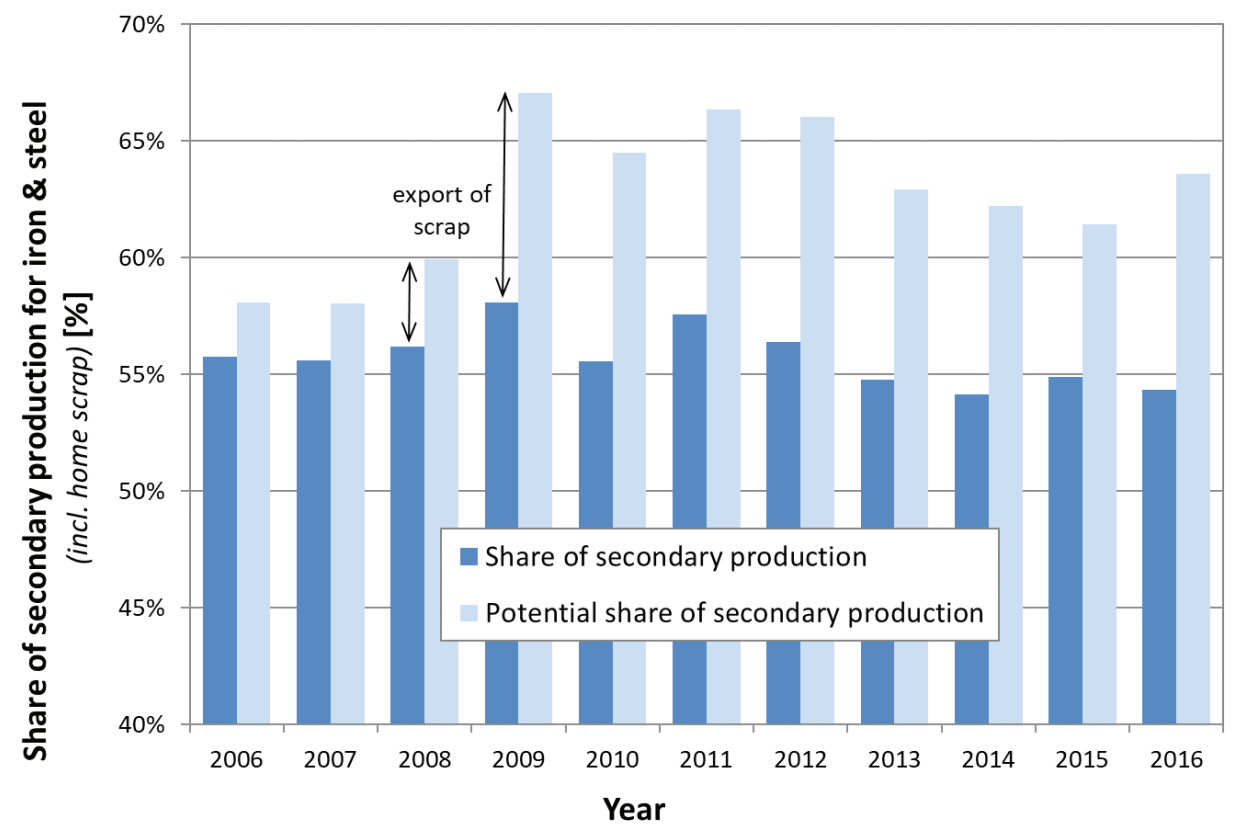

FIGURE 6: Share of secondary production for Iron \& Steel (incl. home scrap) within the European Union for the period 2006 to 2016. The significant increase of the potential share of secondary production between 2008 and 2009 results from the reduction of steel production in the EU during this time (shutdown of steel production plants). 
late) or exported. Hence, the potential of greenhouse gas reduction of $20 \mathrm{~kg} \mathrm{CO}$, eq/cap/y theoretically possible through higher recycling rates (55\%) for packaging Plastics and other Plastics present in MSW will at best only partly be become effective. The "real" emission reduction strongly depends on the substitution achieved by secondary Plastics.

\subsubsection{Paper \& Board}

Current recycling rates for Paper \& Board (83\%) are already very close to the proposed target values (85\%). The improvements required would thus translate into an additional quantity of recyclable waste Paper \& Board of only $2.5 \mathrm{~kg} / \mathrm{cap} / \mathrm{y}$ (equals $1,250 \mathrm{kt} / \mathrm{a}$ ). This is about $2 \%$ of the waste paper quantity generated at present in the EU-28. Assuming that the total additional quantity of waste Paper \& Board is domestically utilized, the share of secondary production would increase to $53.8 \%(+1.3 \%)$.

Considering the recent changes in secondary production (the share rose constantly from $48 \%$ in 2005 to $52.5 \%$ in 2015 - (see Figure 7), this moderate increase seems to be manageable for the European Paper \& Board industry. Quality constrains for Paper \& Board recycling - as highlighted by Pivnenko et al. (2016) - however, might limit the utilization of additional waste paper quantities. The total reduction potential for greenhouse gas emissions by increasing paper recycling rates to $85 \%$ is well below $0.5 \mathrm{~kg}$ $\mathrm{CO}_{2}, \mathrm{eq} / \mathrm{cap} / \mathrm{y}$.

\section{CONCLUSIONS}

Although the analysis was conducted on a rather superficial level (by utilizing and combining highly aggregated data), the results clearly demonstrate that space for improvement in terms of secondary resources utilization in countries with rather highly developed waste management systems in place, like the European Union, is limited and might only slightly increase the quantities of waste derived resources. In case that the ambitious Circular Economy targets for packaging waste are met and also applied to alike non-packaging materials present in MSW, the additional quantities of recyclables available amount to $550 \mathrm{kt} / \mathrm{a}$ for iron and steel $(1.1 \mathrm{~kg} / \mathrm{cap} / \mathrm{y}), 600 \mathrm{kt} / \mathrm{a}$ for aluminum (1.2 $\mathrm{kg} / \mathrm{cap} / \mathrm{y}), 6,500 \mathrm{kt} / \mathrm{a}$ for Plastics (13 kg/cap/y) and 1,250 $\mathrm{kt} / \mathrm{a}$ for Paper \& Board $(2.5 \mathrm{~kg} / \mathrm{cap} / \mathrm{y})$. In case that these secondary materials could substitute the same amount of primary raw materials, annual greenhouse gas emissions of the European industry would be reduced by about 17 Mt $\mathrm{CO}_{2}$,eq (equals $33 \mathrm{~kg} \mathrm{CO}$, eq/cap/y), which is less than $0.4 \%$ of EU's overall greenhouse gas emissions of 4,500 $\mathrm{Mt} \mathrm{CO}_{2}$,eq/a. To which extent other environmental impacts are affected has not been investigated in the present study. This however is subject of ongoing investigations of the authors.

As already today significant amounts of secondary raw materials are not utilized by the European industry but exported for recycling, it is doubtful if the sole prescription of higher recycling targets will result in an increased share of secondary raw material production in the EU. Moreover, since the additional quantities of recyclables (scrap) derived from post-consumer waste are most likely of lower quality than recyclables currently recovered, the risk of down-cycling and thus limited substitution of primary raw materials and also the risk of increased export of recyclables is evident. The trend for the latter is already observable as prices of scrap and recyclables exported from the EU tend to be significantly lower than the ones of imports (Brunner, 2017; Buchner et al., 2015).

Hence, in order to ensure that higher recycling targets will translate into a higher share of secondary production and thus a reduced dependency of European industry from primary resources, additional policy measures (e.g. quota for the share of secondary raw materials utilized) might be required. Furthermore, capacities for the recycling (utiliza-

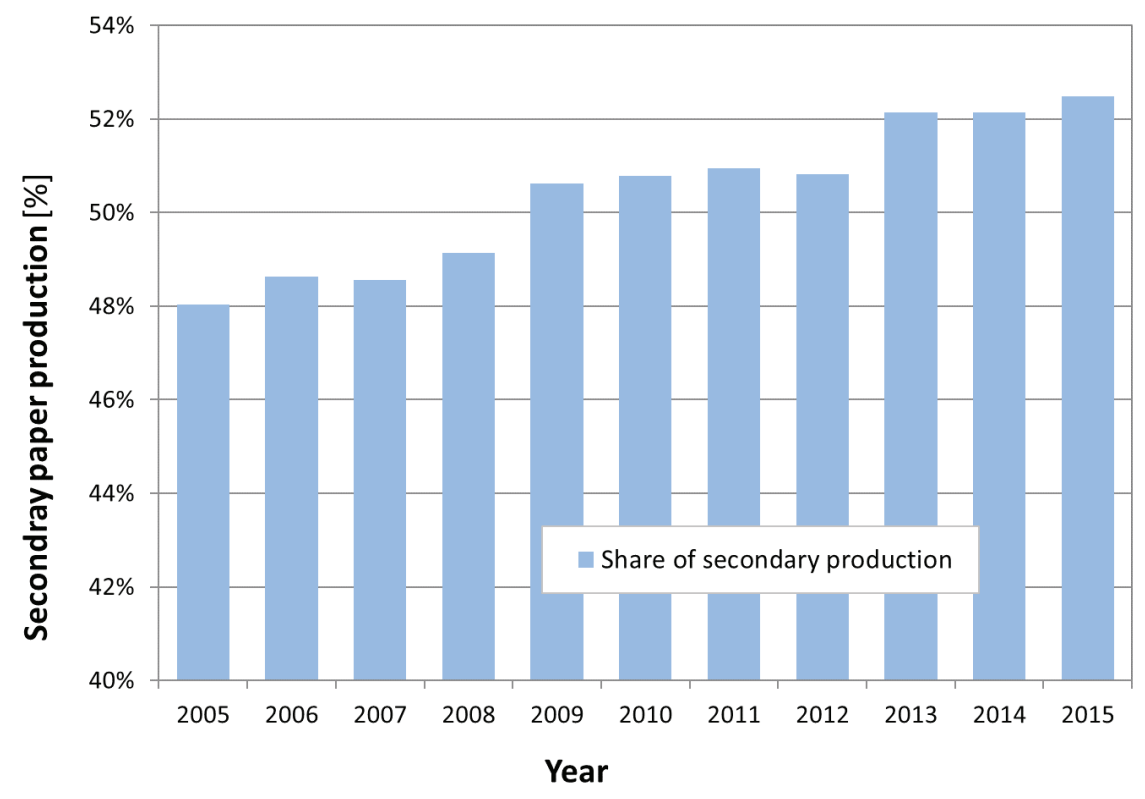

FIGURE 6: Development of secondary production for Paper \& Board within the European Union during the period 2005 to 2015. 
tion) of the additional quantities of secondary raw materials need to be provided, which might represent a challenge, in particular for countries of lower economic development (e.g. Bulgaria, Romania).

The present study analyzed the potential impacts of the circular economy package on the supply and utilization of secondary resources in the EU focusing on material flows only. Impacts on the economics of the commodities, which largely drive the market of secondary resources, have not been considered yet. They should be subject of future investigations.

\section{AKNOWLEDGEMENTS}

The presented work is part of a large-scale research initiative on anthropogenic resources (Christian Doppler Laboratory for Anthropogenic Resources). The financial support of this research initiative by the Federal Ministry of Science, Research and Economy and the National Foundation for Research, Technology and Development is gratefully acknowledged. Industry partners co-financing the research center on anthropogenic resources are Altstoff Recycling Austria AG (ARA), Borealis group, voestalpine AG, Wien Energie $\mathrm{GmbH}$, Wiener Kommunal-Umweltschutzprojektgesellschaft $\mathrm{GmbH}$ and Wiener Linien $\mathrm{GmbH}$ \& Co KG.

\section{REFERENCES}

Brunner, C., 2017. European Circular Economy Strategy - Analysis of Steel, Aluminium and Copper Scrap Flows between the EU-28 and the World, Institute for Water Quality, Resource and Waste Management. TU Wien, Vienna, p. 79.
Brunner, P. H. and H. Rechberger. 2004. Practical handbook of material flow analysis. Boca Raton, Florida: CRC Press LLC.

Buchner, H., Laner, D., Rechberger, H., Fellner, J., 2015. Dynamic Material Flow Modeling: An Effort to Calibrate and Validate Aluminum Stocks and Flows in Austria. Environmental Science \& Technology 49, 5546-5554.

CEPI, 2016. Key Statistics 2015 - European pulp \& paper industry. Confederation of European paper industries, Brussels, p. 32.

Eurofer, 2017. European Steel in Figures Covering 2012- 2016. European Steel Association, Brussels, p. 20

European Aluminium Association, 2016. Aluminium Statistics Europe 2015. European Aluminium Association, Brussels.

Ghenda, T., Lüngen, H.B., 2013. Potential for $\mathrm{CO}_{2}$ Mitigation of the European Steel Industry, IEAGHG/IETS Iron and Steel Industry CCS and Process Integration Workshop. IEAGHG Research Networks, Tokyo, Japan, p. 30.

Oeko-Institut e.V., 2016. Assessment of the Implementation ofDirective 2000/53/EC on End-of Life Vehicles (the ELV Directive) with Emphasis on the End-of Life Vehicles with Unknown Whereabouts. Oeko-Institut e.V., Darmstadt, p. 11.

Pivnenko, K., Laner, D., Astrup, T.F., 2016. Material Cycles and Chemicals: Dynamic Material Flow Analysis of Contaminants in Paper Recycling. Environmental Science \& Technology 50, 12302-12311.

Plastics Europe, 2016. Plastics - the Facts 2015 - An analysis of European Plastics production, demand and waste data, Brussels, p. 38.

Turner, D.A., Williams, I.D., Kemp, S., 2015. Greenhouse gas emission factors for recycling of source-segregated waste materials. Resources, Conservation and Recycling 105, 186-197.

Van Eygen, E., Feketitsch, J., Laner, D., Rechberger, H., Fellner, J., 2017. Comprehensive analysis and quantification of national plastic flows: The case of Austria. Resources, Conservation and Recycling 117, Part B, 183-194.

Verlis, C., 2014. Global recycling markets: plastic waste - A story for one player - China. International Solid Waste Association ISWA, Vienna, p. 66.

Wang, T., Müller, D.B., Graedel, T.E., 2007. Forging the Anthropogenic Iron Cycle. Environmental Science \& Technology 41, 5120-5129.

Warrings, R., Fellner, J., 2017. Where packaging Aluminium gets lost - gaps on the way to a circular economy, Sardinia Waste Conference. CISA, Cagliari, Sardinia, p. 12. 